НАУКОВИЙ ВІСНИК

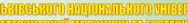

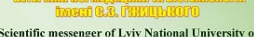

cientific messegger of Livi National University
Veterinary Medicine and Biotechnologies

(n)

TIIT

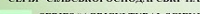

Том 21 № 91

2019
Науковий вісник Дьвівського національного університету ветеринарної медицини та біотехнологій імені С.3. Гжицького. Серія: Сільськогосподарські науки

Scientific Messenger of Lviv National University of Veterinary Medicine and Biotechnologies. Series: Agricultural sciences

ISSN 2519-2698 print

https://nvlvet.com.ua/index.php/agriculture

doi: $10.32718 /$ nvlvet-a9109

UDC 534.63:631.15

\title{
Perspective ecological processes of agricultural sewage water treatment when using non-traditional sorbents
}

\author{
O.V. Matsuska, M.V. Tsizhovska, D.M. Khapko
}

Stepan Gzhytskyi National University of Veterinary Medicine and Biotechnologies Lviv, Ukraine

Article info

Received 09.09.2019

Received in revised form 08.10 .2019

Accepted 09.10.2019

Stepan Gzhytskyi National University of Veterinary Medicine and Biotechnologies Lviv, Pekarska Str., 50, Lviv,

79010, Ukraine.

Tel.: +38-067-25-99-539

E-mail:kasanam@meta.ua

\begin{abstract}
Matsuska, O.V., Tsizhovska, M.V., \& Khapko, D.M. (2019). Perspective ecological processes of agricultural sewage water treatment when using non-traditional sorbents. Scientific Messenger of Lviv National University of Veterinary Medicine and Biotechnologies. Series: Agricultural sciences, 21(91), 54-59. doi: 10.32718/nvlvet-a9109
\end{abstract}

The usage of natural sorbents in sewage water treatment technologies, in particular agro-industrial complex, has a number of environmental and economic advantages. Non-traditional sorbents, which are concentrated in many parts of Ukraine, are cheap raw materials for sewage water treatment. The sorption properties of the upland and lowland peat species of the Gamalivka-Grybovychi deposit, which were studied early, indicate their high sorption capacity for ammonium ions, which, if they enter water bodies, cause a number of environmental problems. According to the results of the ecological assessment of sewage water of meat processing facility, the chicken processing facility and milk processing plant, it was found out the exceedance of the acceptable limits for the content of ammoniacal nitrogen, respectively: 1.3-3 MPC; 3.8 MPC and 2.5 MPC. This component is a water pollutant and a "crop" of yield in agriculture, since nitrogen is an important element of plant nutrition. The rational usage of natural resources involves the complex usage of natural resources. The nitrogen absorbed by ammonium peat, as well as the peat itself is a sufficient fertilizing land, so the use of used peat complex in agriculture allows to solve not only problems of fertilizers, but also to achieve greening in sewage water treatment technologies. Greening as a whole is a result of waste minimization, and today there are two main areas: new technological non-waste technology together with low-waste technology and waste regeneration. This paper presents a comparison of the physiological indices of plants, depending on the application of the species and form of Gamaliivka-Grybovychi peat deposit, Yavoriv district, when fertilizing the substrate (sand as a background) of the study areas. The influence on the quality of ascent and growth of vegetative culture-watercress, natural form of the top and lowland peat species, as well as their waste forms obtained as a result of the process of purification of ammonium ions, modeling the sewage water of the agro-industrial complex, was investigated. The mass of the harvest from the experimental fields was determined and compared. The differences of lowland and upland peat species are due to its origin, which significantly affects their chemical composition. The plants fuelled with peat are much higher in the mass than those crops that were grown with adding of peat substrate into the lowland. However, the used form of lowland peat provided a 1.57 times higher harvested crop yield than the used upland sample of the studied sorbent.

Key words: agricultural industry, sewage water, pollution, ammonium nitrogen, peat, adsorption, fertilizer, greening.

\section{Перспективи екологізації процесу очищення стічних вод АПК при використанні нетрадиційних сорбентів}

О.В. Мацуська, М.В. Ціжовська, Д.М. Хапко

Львівський національний університет ветеринарної медичини та біотехнологій імені С.3. Гжицького, м. Львів, Украӥна 
Використання у технологіях очищення стічних вод, зокрема агропромислового комплексу, природних сорбентів має ряд еколого-економічних переваг. Нетрадииійні сорбенти, поклади яких зосереджено у багатьох районах Украӥни, є дешевою сировиною для очищення стоків. Попередньо дослідженні сорбиійні властивості верхового та низинного видів торфу родовища ГамаліївкаГрибовичі, вказують на їх сорбчійну здатність до йонів амонію, які при недостатньому вилученні зі стічних вод, потрапляючи у водні об'єкти спричинюють ряд екологічних проблем. За результатами аналізу екологічної очінки стічних вод м'ясопереробних підприємств, птахофабрик та молокозаводів, встановлено перевищення допустимих норм за вмістом азоту амонійного: 1,33 ГДК; 3,8 ГДК та 2,5 ГДК відповідно. Даний компонент являється забруднювачем води, а у сільському господарстві - “покрашувачем” врожайності, оскільки Азот є важливим елементом живлення рослин. Раціональне використання природних ресурсів включає в себе комплексний підхід до їх застосування. Сорбований азот амонійний торфом, а також сам торф є піджсвою угідь, тому застосування відпрацьованого торфового комплексу у сільському господарстві дозволяє вирішувати не лише проблеми удобрення, а й досягнути екологізації у технологіях очищення стічних вод. Екологізація в иілому є наслідком мінімізації відходів, $і$ на сьогодні виділяють два основних напрямки: нові технологічні безвідходні та маловідходні прочеси та регенерація відходів. У даній роботі наведено порівняння фізіологічних показників рослин, залежно від застосування виду та форми торфу родовища Гамалї̈ка-Грибовичі Яворівського району, при удобренні субстрату (пісок як фон) дослідних ділянок. Досліджено вплив на якість сходження та росту тестової культури - крес-салату, природної форми верхового та низинного виду торфу, а також їх відпрацьованих форм, одержаних в результаті процесу очищення водного середовища від йонів амонію, щзо моделює стічні води агропромислового комплексу. Визначено та порівняно маси зібраного врожаю із дослідних ділянок. Відмінності низинного і верхового видів торфу обумовлені його походженням, щуо суттєво позначається на їх хімічному складі. Рослини, підживлені верховим видом торфу, значно перевищили у масі тих культур, які вирощувались при внесенні до субстрату його низинного виду. Проте відпрацьована форма низинного торфу забезпечила одержання більшої маси зібраного врожаю в 1,57 разу, ніж відпрацьована верхова проба досліджуваного сорбенту.

Ключові слова: АПК, стічні води, забруднення, амонійний азот, торф, адсорбція, добриво, екологізація.

\section{Вступ}

Чимало наукових досліджень, що здійснюються в області очищення стічних вод, присвячено застосуванню природних сорбентів для вилучення широкого спектру забруднюючих компонентів (Macus'ka et al., 2010; Borkowski et al., 2012; Mal'ovanyj et al., 2013; Petrushka et al., 2018). При цьому є ризик утворення та накопичення певних об'ємів вторинних відходів “відпрацьованих сорбентів". Важливим аспектом у вирішенні даного питання є комплексний підхід до раціонального використання природних ресурсів, що вимагає екологізації виробництв. Згідно з Законом України "Про затвердження загальнодержавної програми розвитку мінерально-сировинної бази України на період до 2030 року”, використання мінеральносировинних ресурсів повинно базуватися на впровадженні новітніх ресурсозберігаючих технологіях (Zakon Ukrai'ny vid 21 kvitnja 2011 roku).

Відомо, що очищення стічних вод м'ясопереробних підприємств природним мінеральним сорбентом - цеолітом не лише дозволяє знизити вміст забруднюючих компонентів у стоках, таких як амонійний азот, фосфати, білок, а й забезпечує поліпшення врожайності сільськогосподарських культур, через застосування відпрацьованого цеолітового комплексу для удобрення грунту (Macus'ka et al., 2011).

Дослідження сорбційної здатності різних природних сорбентів (поклади яких на території України є значними) до компонентів стічних вод АПК, з метою забезпечення екологізації технологій очищення стоків $\epsilon$ актуальним питанням сьогодення.

Торф - це органічна гірська порода, що утримує близько 50\% мінеральних речовин, утворена внаслідок відмирання й неповного розпаду болотних рослин за умов надмірної вологи й недостатнього доступу повітря. У межах Львівської області нараховують 168 родовищ торфу, площа промислової глибини яких становить 51606 га, а геологічні запаси - 158802 тис. т (Blazhko \& Kiptach, 2012).
Залежно від характеру залягання торф поділяють на три типи: верховий, перехідний та низинний. Відмінності низинного і верхового торфу обумовлені походженням і родовищем болота. Зазвичай верховий торф виникає в регіонах з суворими умовами і бідною рослинністю. В болотах на рівній поверхні, де підводних вод практично немає, а живлення відбувається від танення снігів і рідких опадів, утворюється торф при розкладанні сфагнуму, пухівки, вересу, сосни, багна.

Низинний торф зустрічається у ярах, берегах річок, де можливе живлення від грунтових вод. Утворюється даний вид торфу при розкладанні хвоща, очерету, осок, мохів і деревних порід. До його складу входять і поживні речовини, які, стікаючи, захоплювали грунтові води.

Походження торфу позначається і на його хімічному складі. Верховий торф кислий - 3-4 pH, у низинного, в якому органіки 70\%, реакція слабо-кисла або нейтральна $-5,5-7 \mathrm{pH}$. Солей в останньому міститься багато - 200-700 мг/л, у верхівковому - до 70$180 \mathrm{мг/л.}$

Отже, торф у своєму складі містить:

- рослинні волокна, що поліпшують водноповітряний стан грунту;

- гумінові кислоти, які активують ріст рослин;

- елементи мінерального живлення - Азот, Калій, Фосфор, Кальцій, Залізо, Магній, мікроелементи.

Вважається, що верховий торф є ідеальним субстратом для вирощування лохини, журавлини, чорниці, рододендронів та хвойних, а при посадці інших культур варто його попередньо розкислювати. Природна структура низинного торфу дозволяє використовувати його для будь-яких рослин. Даний вид торфу містить 3\% Азоту у такій формі, якій рослини засвоюють дуже повільно. У зв'язку з цим його попередньо рекомендується компостувати або збагачувати додатково Азотом.

Метою роботи було дослідити фізіологічні показники сходу, росту та маси вирощених рослин при їх підживленні різними видами торфу - верхового та 
низинного торфовища Гамаліївка-Грибовичі, а також їх відпрацьованих форм, одержаних як відходи в результаті здійснення процесу адсорбції.

\section{Матеріал і методи досліджень}

При дослідженні процесу сорбції йонів амонію на верховій та низинній пробах торфу родовища Гамаліївка-Грибовичі із водного середовища, нами було встановлено їх сорбційні ємності до даного компоненту. Сорбційна здатність низинної проби торфу до йонів амонію є вищою від сорбційної здатності верхової проби торфу в 1,26 разу і становить відповідно: 0,98 мг/г та 0,78 мг/г (Blazhko \& Kiptach, 2012).

Азот амонійний $є$ одним із біогенних елементів, які, потрапляючи в об'єкти довкілля із стічними водами, особливо при значному перевищені допустимих значень (у стоках м'ясопереробних підприємств, птахофабрик та молокозаводів перевищення норми відповідно: 1,3-3 ГДК; 3,8 ГДК та 2,5 ГДК), спричинюють ряд екологічних проблем. Проте у сільському господарстві, даний досліджуваний компонент $\epsilon$ важливим елементом живлення рослин, адже Азот входить до складу рослинних білків, амінокислот, нуклеїнових кислот та інших життєво важливих сполук. Рослини засвоюють лише мінеральний Азот у формі йонів амонію $\left(\mathrm{NH}_{4}^{+}\right)$та нітрат-йонів $\left(\mathrm{NO}_{3}^{-}\right)$. За нестачі азоту спостерігається гальмування росту рослин, послаблюється утворення бокових пагонів і коренів, спостерігається дрібнолистковість, тощо. Основною зовнішньою ознакою дефіциту Азоту є блідо-зелене забарвлення листків, поява некрозів, висихань і відмирань тканин.

Для встановлення можливості екологізації технології очищення стічних вод, особливо агропромислового комплексу, було проведено вегетаційні дослідження, що відтворювали реальні умови вирощування сільськогосподарських культур при різних удобреннях субстрату. Режим підживлення та поливу рослин відповідав процесу їх вирощування у тепличних господарствах (Macus'ka et al., 2017).

Норма внесення аміачних добрив на 1 га ріллі під овочеві культури становить 220 кг, тому дана дослідна ділянка, приготовлена для досліджень, (0,03 м²) потребує $\sim 0,67$ гр даного елементу живлення. Враховуючи сорбційну здатність торфу до йонів амонію, а також природний вміст азоту, у складі торфу (на 1 т торфу 20 кг Азоту, 3\% із якого засвоюється рослинами), то на дослідну площу внесено по 40 мг висушених проб торфу (втрата вологи при сушінні (Т $60 \pm 3{ }^{\circ} \mathrm{C}$ ) низинного та верхового торфу становить відповідно: 55-62\% та 20-27\% ) та у таких же кількостях їх відпрацьованих форм.

Для дослідження впливу добрив на кінетику росту рослин ставили п'ять паралельних досліди: пісок без удобрення (контроль); пісок + верхова проба торфу; пісок + низинна проба торфу; пісок відпрацьований верховий торф та пісок + відпрацьований низинний торф.

В горщечки висівали крес-салат, який є тестовою культурою (по 150 зернят). Протягом вегетаційного періоду проводився догляд та спостереження за рос- линами (спушування піску, полив (500 мл). Рослини фотографували (рис. 1, 2) та порівнювали їх ступінь розвитку.

Дані експериментальні дослідження проводились у весняний період року, тому такі фактори, як тривалість світлового дня, температура повітря були досить сприятливими для вирощування даної культури. Період вегетації тривав 14 днів. Важливо підкреслити, що субстратом для вирощування рослин обрано пісок (як фон), який не містить необхідних елементів живлення для їх росту, що дає можливість оцінити та порівняти саме вплив досліджуваних удобрюючих компонентів на розвиток даної тест-культури.
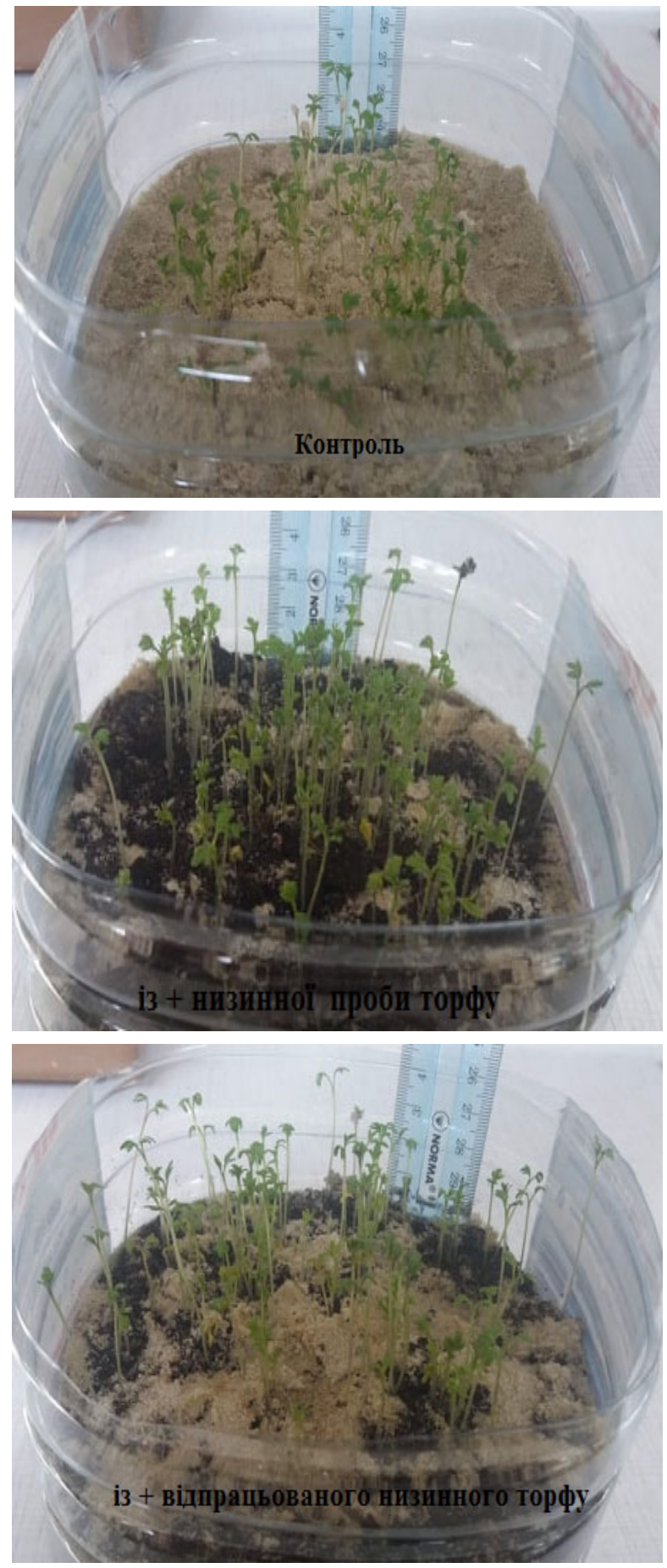

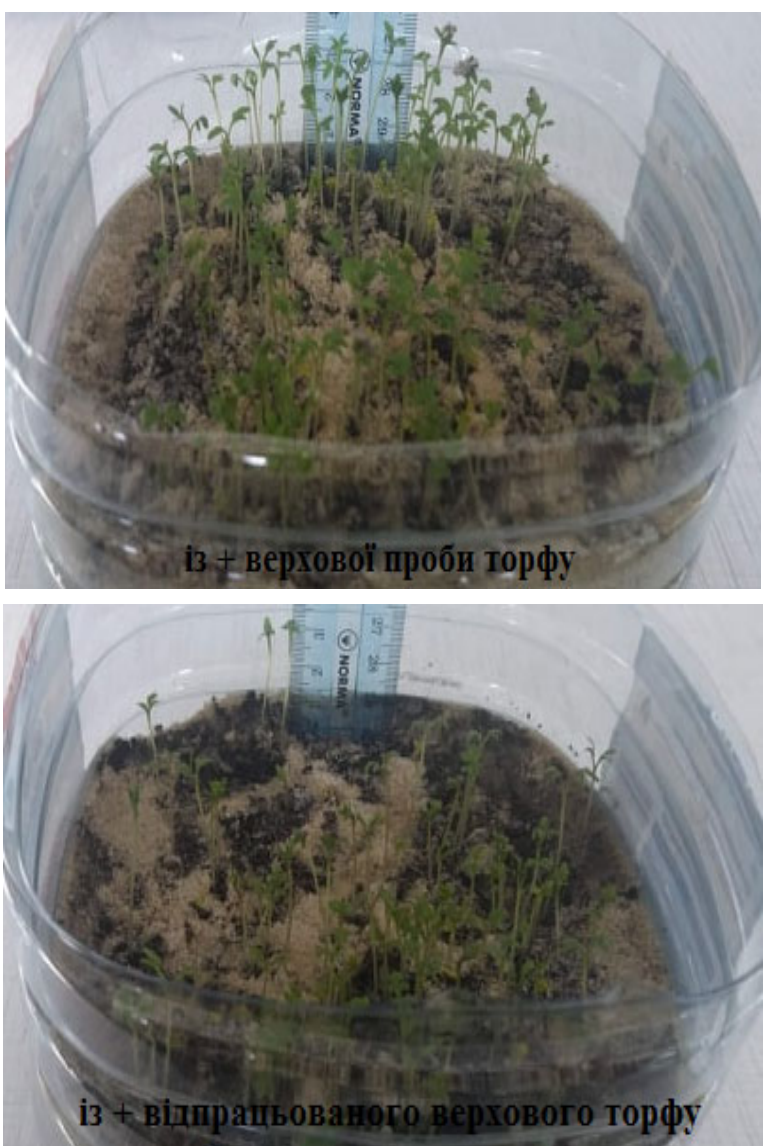

Рис. 1. Порівняння сходження та росту рослин залежно від агротехніки на 5 день вегетації
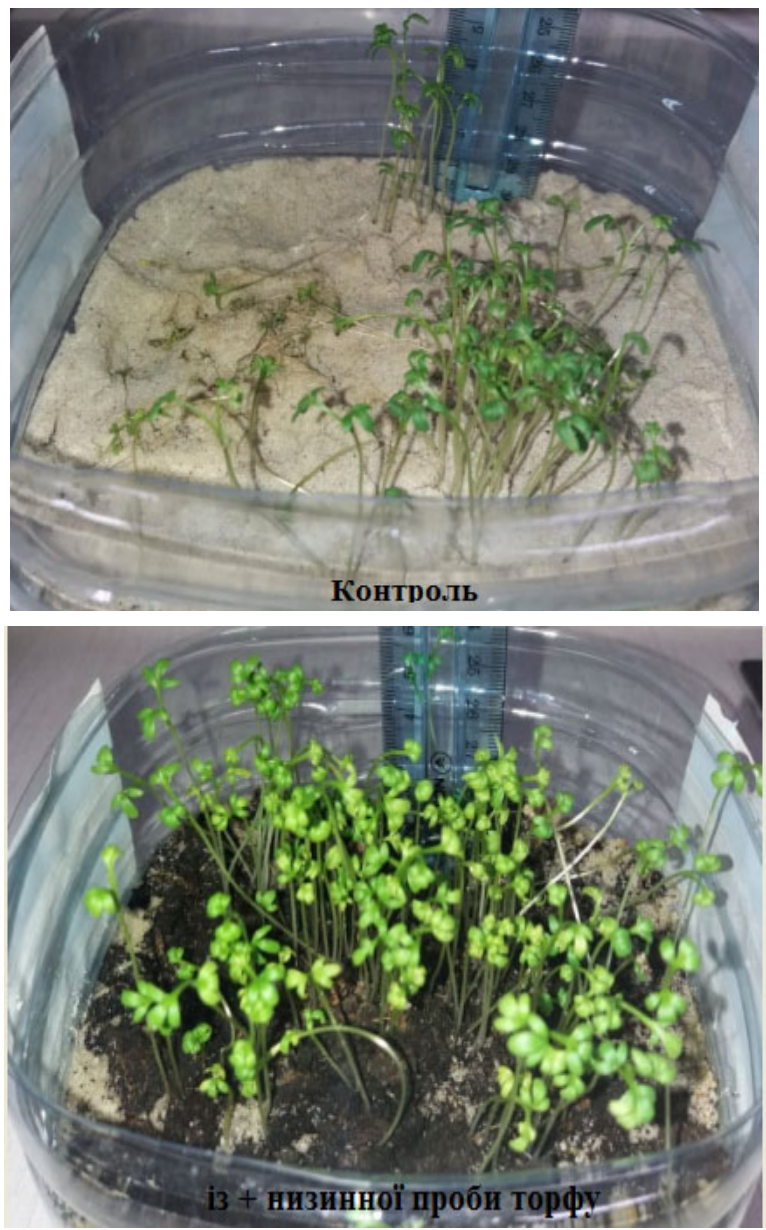
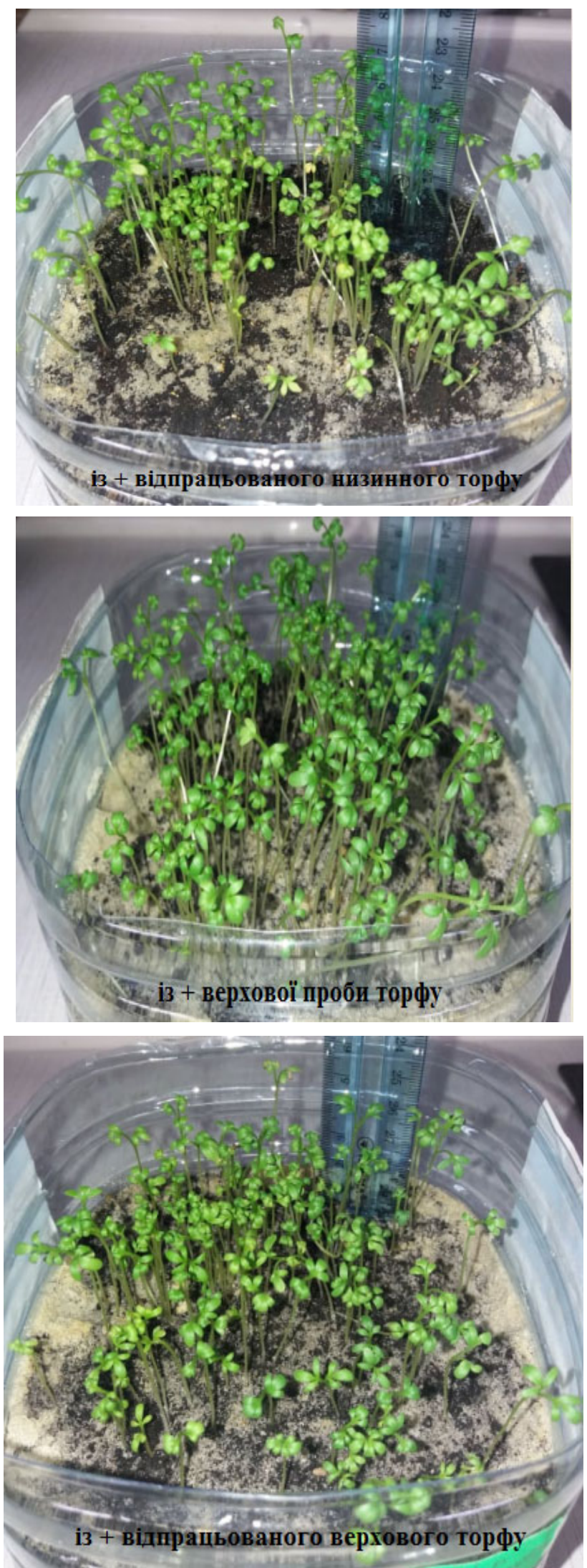

Рис. 1. Порівняння росту рослин залежно від агротехніки на 13 день вегетації

Аналізуючи фізіологічні показники рослин на 5 день вегетаційного періоду (рис. 1), спостерігали відставання у сходженні та рості рослин, які вирощувались на контрольній ділянці та із додаванням відп- 
рацьованої форми верхового торфу. Сходження рослин, що вирощувались без удобрення, становило 64\% та станом на цю добу їх ріст був у межах 2-2,5 см. Рослини підживлені низинним видом торфу сягали 2,5-3,5 см, їх сходженість на даній ділянці досягнула 82\%. Відпрацьована форма низинного торфу поліпшила показник сходу рослин до $94 \%$ та їх висоти до 3-4 см. Найкращою появою вирізнялися рослини, які росли при додаванні до піску верхового торфу - 99\%, їхня висота становила - 3-3,5 см. Проте на ділянці 3 додаванням відпрацьованого верхового торфу рослини відставали у рості - 2-3 см, їхня кількість була $86 \%$.

На 13 день досліджень (рис. 2) бачимо, що 20\% рослин на контрольній ділянці зів'януло, це вказує на нестачу необхідних елементів для їх живлення. Також стебла цих рослин є досить тонкими, максимальна їх висота перед збором урожаю - 3-4,5 см. Природні види торфу забезпечують належний ріст та розвиток крес-салату, проте висота рослин при підживленні верховим торфом була дещо кращою, ніж при вирощуванні ї із низинною пробою торфу: 4,5-6 см та 45,5 см відповідно. Спостережено також неоднаковий вплив відпрацьованих форм сорбентів на розвиток досліджуваних культур: відпрацьований низинний торф, порівняно із його природною формою, підвищує ефективність росту рослини у 1,5 разу (висота рослин досягнула 6-7,5 см). Відпрацьований верховий торф дещо пригнітив ріст крес-салату, висота його пагонів на 13 день вегетативного періоду становила 3-4,5 см, що у 1,5 рази нижче від ефективності росту рослин при вирощуванні їх 3 природним верховим торфом.

Досить важливим параметром, який відображає ефективність та доцільність застосування відпрацьованих форм сорбентів для підживлення рослин, $є$ маса вирощеного урожаю. Тому на завершальному етапі вегетативних досліджень рослини були зібрані та висушені до їхньої постійної ваги. Порівняння одержаних мас рослин, які вирощувались при різних удобреннях субстрату, відображено у таблиці 1.

\section{Таблиця 1}

Порівняння одержаних мас рослин, що вирощувались при різних удобреннях дослідних ділянок

\begin{tabular}{clc}
\hline № п/п & Назва удобрюючого компоненту & Маса рослин, гр \\
\hline 1 & Контроль: без підживлення & 0,16 \\
2 & Низинна проба торфу & 0,41 \\
3 & Відпрацьований низинний торф & 0,69 \\
4 & Верхова проба торфу & 0,69 \\
5 & Відпрацьований верховий торф & 0,44 \\
\hline
\end{tabular}

Аналізуючи дані таблиці 1, бачимо, що маса рослин підживлених верховим видом торфу у 1,6 разу вища, ніж тих, що вирощувались із додаванням низинного виду торфу. Проте відпрацьована низинна форма торфу забезпечила вищу ефективність зібраного врожаю, ніж відпрацьована верхова форма торфу в 1,57 разу.

\section{Висновки}

Отримані результати вегетативних досліджень вказують на перспективу мінімізації відходів, які утворюються в результаті здійснення процесу сорбції йонів амонію із води за допомогою торфу родовища Гамаліївка-Грибовичі, шляхом застосування їх як удобрюючих компонентів для сільськогосподарських угідь. Сорбційна здатність низинного торфу до йонів амонію із водного середовища $\epsilon$ вищою у 1,28 разу ніж сорбційна здатність верхового торфу. Відпрацьована форма низинного виду торфу дає вищу ефективність врожайності рослин при їх підживлені, ніж відпрацьована верхова проба торфу в 1,57 разу.

У порівнянні 3 контролем (пісок), використання для удобрення природного низинного торфу поліпшує усі досліджувані фізіологічні показники вирощеної культури, приріст маси становить 2,56 разу, а при додаванні відпрацьованої форми даного виду сорбенту покращується врожайність у 4,31 разу щодо контролю та 1,68 разу порівняно із застосуванням його природної форми. Природний верховий торф забезпечує збільшення маси зібраних рослин щодо контролю у 4,31 рази, а відпрацьована його форма - у 2,75 разу. Проте відпрацьований сорбент верхового виду торфу знижує вагу вирощених культур щодо його природної форми у 1,57 разу.

Перспективи подальших досліджень. Буде досліджено сорбційну здатність даних видів торфу до фосфатів як одного із забрудників стоків АПК та поряд із цим важливого елементу живлення для рослин. Необхідність встановлення впливу відпрацьованих торфових комплексів із вмістом фосфатів на фізіологічні показники вирощування культур показує перспективу подальших досліджень.

\section{References}

Blazhko, N., \& Kiptach, F. (2012). Analiz stanu vykorystannja torfovyh resursiv L'vivs'koi' oblasti. Visnyk L'vivs'kogo universytetu. Serija geografichna, 40(1), 107-113. http://old.geography.lnu.edu.ua/Publik/ Period/visn/40(1)/PDF/011_Blazhko,\%20Kiptach.pdf (in Ukrainian).

Borkowski, A., Rydelek, P., \& Szala, M. (2012). Charakterystyka procesu adsorpcji azotetrazolanu w gruntach organicznych na przykładzie torfu. Inżyneria Ekologiczna, 29, 17-25 (in Ukrainian).

Macus'ka, O.V. Paranjak, R.P., \& Gumnyc'kyj, Ja.M. (2011). Doslidzhennja fiziologichnyh pokaznykiv roslyn pid chas i'h udobrennja sorbentom z komponentamy stichnyh vod. Naukovyj visnyk L'vivs'kogo nacional'nogo universytetu veterynarnoi' medycyny ta biotehnologij im. S.Z. Gzhyc'kogo, 13, 4(50), 291-296. http://nbuv.gov.ua/UJRN/nvlnu_2011_13_4\%284\%29 58 (in Ukrainian).

Macus'ka, O.V., Kalyn, B.M., \& Pavljuk, I.O. (2017). Porivnjal'nyj analiz vykorystannja pryrodnyh sorbentiv u procesah ochyshhennja stokiv pidpryjemstv APK. Naukovyj visnyk LNUVM ta BT im. S.Z. G'zhyc'kogo, 19(79), 159-162. 
https://nvlvet.com.ua/index.php/agriculture/article/vie w/2800 (in Ukrainian).

Macus'ka, O.V., Paranjak, R.P., \& Gumnickij, Ja.M. (2010). Adsorbcija komponentov stochnyh vod prirodnymi sorbentami. Himija i tehnologija vody, 42(4), 399-408 (in Russian).

Mal'ovanyj, M.S., Sakalova, G.V., \& Chornomaz, N.Ju. (2013). Doslidzhennja kinetyky osadzhennja pryrodnyh sorbentiv u vodi pislja i'h vykorystannja dlja ochyshhennja pytnoi' vody vid joniv amoniju. Visnyk Hmel'nyc'kogo nacional'nogo universytetu, 1, 265-268. http://journals.khnu.km.ua/vestnik/pdf/tech/2013_1/54 mal.pdf (in Ukrainian).

Palamarchuk, V.D., Polishhuk, I.S., Jermakova, L.M., \& Kalens'ka, S.M. (2012). Systemy suchasnyh intensyvnyh tehnologij. Vinnycja: FOP Rogal's'ka I.O. (in Ukrainian).

Petrushka, I.M., Moroz, O.I., \& Petrushka, K.I. (2018). Racional'ne vykorystannja pryrodnyh resursiv u tehnologii' ochyshhennja stichnyh vod. Ekonomika i suspil'stvo, 15, 585-589. http://economyandsociety.in.ua/journal/ 15_ukr/89.pdf (in Ukrainian).

Zakon Ukrai'ny vid 21 kvitnja 2011 roku "Pro zatverdzhennja Zagal'noderzhavnoi' programy rozvytku mineral'no-syrovynnoi' bazy Ukrai'ny na period do 2030 roku" Rezhym dostupu: https://zakon.rada.gov.ua/laws/show/3268-17 (in Ukrainian). 